\title{
"Once Upon a Time in America" and the End of the American Dream
}

\section{Fabrizio Pezzani*}

Department of Business Administration, Accounting and Control, Department of Policy Analysis and Public Management, Bocconi University, Italy

\begin{abstract}
History repeats itself over time because the human soul never changes, but continuously oscillates between good and evil. Freewill in uncertain decision-making is the tightrope we walk, the difficulty of understanding whether our actions are right or wrong, and whether we pursue the good or the bad. In this sense, man's history tends to repeat itself cyclically, because human societies identify themselves variously in Cain or Abel. The history of societies and civilizations is linked to their birth, development, decline, and death. Man is perpetually confronted with changing environmental contexts and the potential for a society's growth and development lies in its ability to creatively face the challenges and respond to the new demands of history.
\end{abstract}

Keywords: Individualism; Social capital; Civilization on trial; Anthropological crisis; Human soul unchangeable; Capitalism euthanasia; Illusion of paper money; Inequality; Mortal greed

\section{Introduction}

Societies grow to the extent that creative minorities succeed in renewing people and the governance rules by adapting to changing conditions. When these minorities lose their creativity, and pursue personal goals and not those of a common good, all societies in history tend to ossify and autistically repeat their responses to a changing world. From that moment, the downfall begins that can last for even hundreds of years, as in Roman society/civilization, until the reticular system of social relations that maintains a society suddenly disintegrates, yet the implosion began long ago. This interpretation enables understanding the evolution of the USA sociocultural model that in the post-war era was the emblem of democracy and today is torn apart by internal conflicts that seem unmanageable.

Unfortunately, there are no easy or immediate solutions and requires rethinking a system that has degenerated into the oligarchy and unbridled individualism that is devastating society. The reference to Sergio Leone's film is a significant reinterpretation of the pain and loss of lost ideals, such as solidarity and friendship.

\section{The End of the "American Dream": The Pain and Regret for What Has Been Lost Over Time and the Cyclical Trend in History.}

"Once Upon a Time in America ": The end of the "American Dream ".

"Once Upon a Time in America" is a 1984 film co-written and directed by the legendary Sergio Leone as part of the time and memory trilogy following "Once Upon a Time in the West" and "Duck, You Sucker!". All these films are set in the USA and are marked by a profound note of sadness and nostalgia for a past that had represented a part of the history of this country and changes related to human affairs [1-3]. The historical theme is closely linked to that of nostalgia, a term composed of two Greek words- "nostos", time, and "algos", pain- that together express the pain and regret in the passing of time for what is lost. These films show the evolution of history through the sentiments that animate the human spirit and give evidence that our history is a series of phases and times that in their own way follow a cyclical trend as GB Vico had already anticipated in 1725 in "The New History" in which he highlighted its cyclicality. The last in the trilogy is a film of the transformation of a great country that for years represented the democratic ideals and now torn apart by fierce internal wars led by an oligarchy, falsely masked as democracy, struggling to maintain a dominant role also against the teachings of history at the cost of imploding the country.

The story in the film takes place from the beginning of the century to 1968 with a dramatic epilogue and represents the year of the turning point of USA history, in its own way the "annus horribilis", the end of the dreams of equality and democracy to embark on a socio-cultural adventure that would sweep away the ancient dreams of ruthless individualism in which friendship became a pure act of utility. The extended period of a century narrated in the film was the hope of the many who came as emigrants to Ellis Island and saw in the Statue of Liberty a welcoming mother. The poem of Emma Lazarus engraved at her feet states welcomingly "Give me your tired, your poor, your huddled masses yearning to breathe free, the wretched refuse of your teeming shore. Send these, the homeless, tempest-tossed to me, I lift my lamp beside the golden door!" [4,5]. In the face of this liberating and peaceful reception, the story unfolds of a band of youths who entered the circuit of the underworld and then, thanks to prohibition, rapidly thrived. This was the period before the Great Depression, the first real drama in the country that would be resolved through a return to the social equilibrium that had even then been destabilized by financial speculation. The friendship between the youngsters from the Jewish ghetto, like other conclaves-little Italy, Chinatown...- represented a distant edge of the land that strengthened and formed a union that at the end of prohibition in the thirties to the end of the Great Depression dramatically disassembled for the onset of greed and selfishness. This historical period deeply marked the country that was brought back to social equilibrium by a redistributive politics and rebuilding the social capital that is the foundation of a prosperous economy. Roosevelt himself in his inaugural address of 1937 stated, "We have always known that heedless self-interest was bad morals; we know now that it is bad economics" [6-9]. Thus, once again the history often forgotten by

*Corresponding author: Fabrizio Pezzani, Department of Business Administration, Accounting and Control, Department of Policy Analysis and Public Management, Bocconi University, Italy, Tel: +39 025836 2594-5; Fax: +39 025836 2593; E-mail: fabrizio.pezzani@unibocconi.it

Received July 05, 2017; Accepted July 10, 2017; Published July 20, 2017

Citation: Pezzani F (2017) "Once Upon a Time in America" and the End of the American Dream. J Socialomics 6: 208. doi:10.4172/2167-0358.1000208

Copyright: () 2017 Pezzani F. This is an open-access article distributed under the terms of the Creative Commons Attribution License, which permits unrestricted use, distribution, and reproduction in any medium, provided the original author and source are credited. 


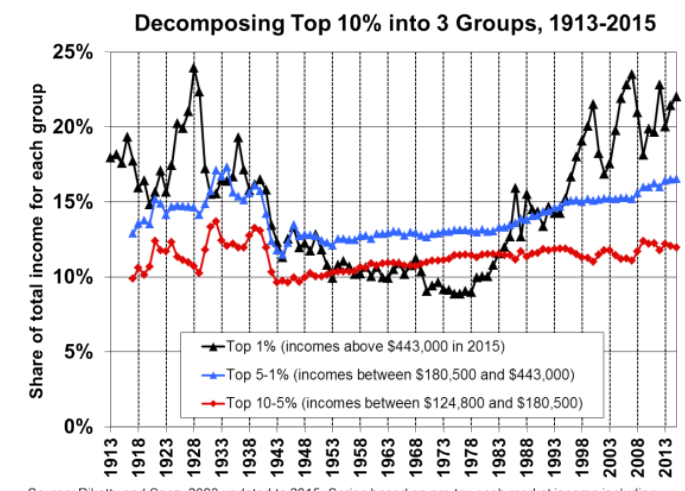

a.

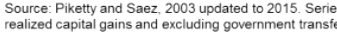

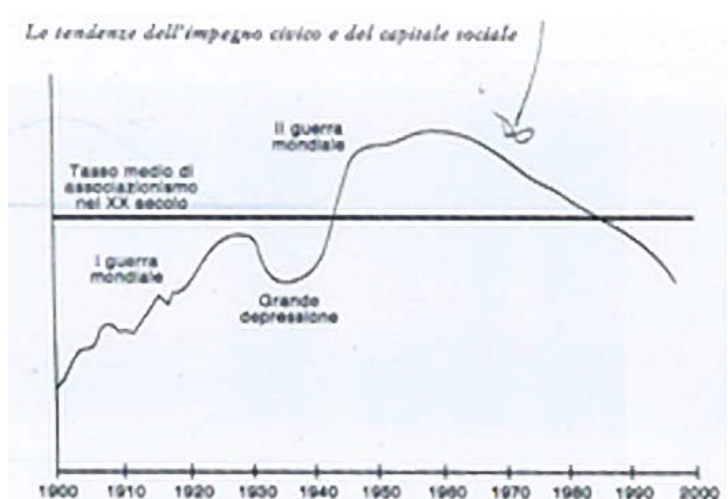

Figures 1a-1b: Correlation between social capital and economic capital.

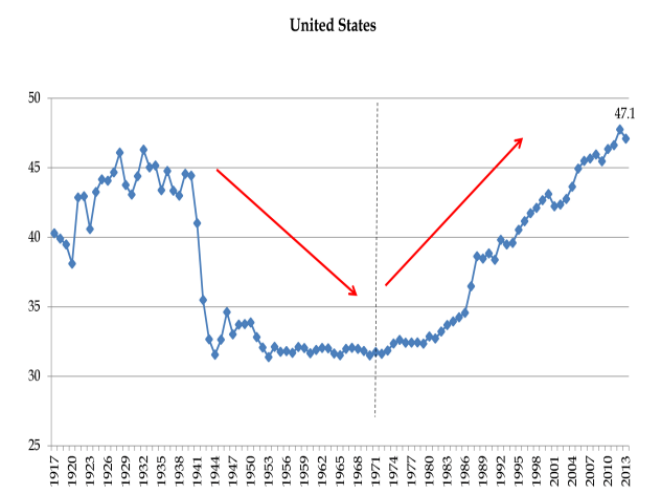

a.

c.

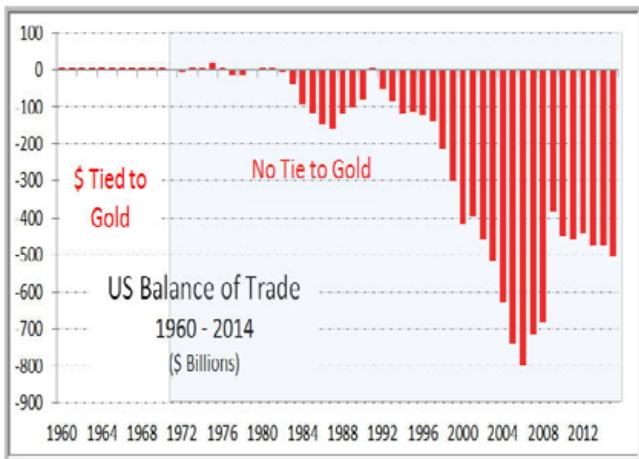

man leads to wisdom and conscious collaboration because no society can survive over time unless it is based on familistic principles. That period saw reconciliation with attention to the value of the person and not just the principle of economics, as instead is the case today. As Keynes stated, it is better to pay people to dig holes in the ground and then fill them up than leave them unemployed. However, Keynes was a true economist because he was first a social scientist- he would find in the war against Nazism the sense of love and reconstruction where economic development would be accompanied by the rebuilding of solid social capital. The years after the war were the emblem of democracy that seemed to always be a dream or utopia, but in a limited time span, because at the end of the sixties American history definitively turned the page. Precisely in 1968, the story of the former friends takes a final turn in the film as the drama of greed and selfishness that one of the four youngsters faced clashed with the reality of history that always presents the bill, and so he became a wealthy financier and politician of fame, having to account to the survivor of the infamy that engulfed the old friendship. In the final scene, the rich politician prefers suicide while a car full of youngsters passes by singing "God bless America".

\section{America Changes Spirit: 1968, the "Annus Horribilis"}

It was the dramatic year of 1968 and America would from then on must face the drama of greed, selfishness, and damnation resulting from the loss of the sense of society that with difficulty was built after the 
a.

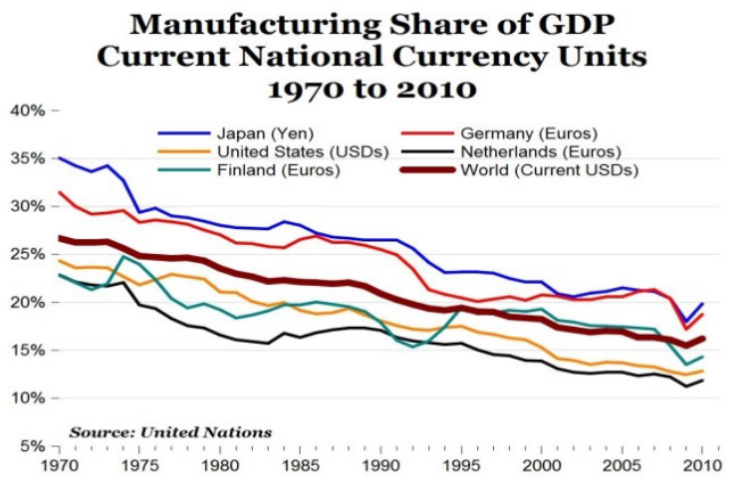

b.

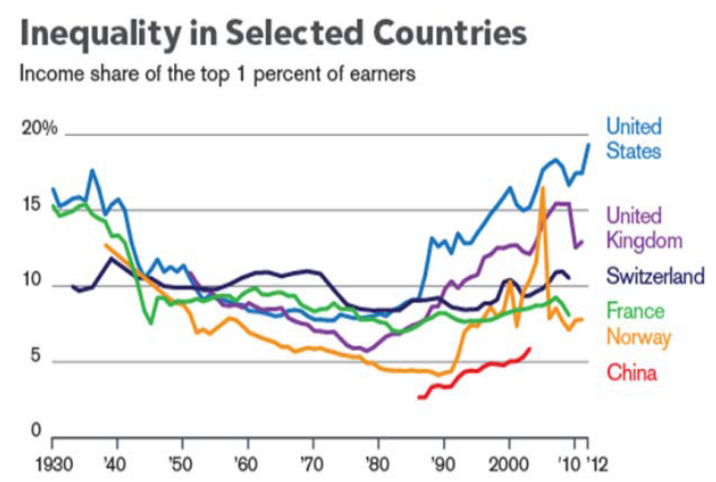

Figures 3a-3b: Graphs depict the end of the dream of equality and democracy that occurred in the same period as the end of the gold exchange standard.

war [10-15]. The following graphs clearly show the correlation between social capital and economic capital, and the trend demonstrates that the instability of the human soul is its eternal damnation (Figures 1a and $1 \mathrm{~b})$.

The graphs show the correlation between society (capital stock) and the economy (economic capital). The turnaround is evident from a positive to a negative trend since the early seventies after the termination of the convertibility of the USA dollar to gold [16-18]. Since 1971 , with the end of the currency's convertibility into a really goodthe gold exchange standard- economics falsely turned into an exact science, with infinite and totally deregulated finance that dragged us towards today's global chaos. Paper money, illusory debt, systematic market manipulation, and social disquiet exploded, as can be seen in the following graphs (Figures $2 \mathrm{a}-2 \mathrm{~d}$ ).

The destructive shareholder value creation mantra led to desolating delocalization, destroying manufacturing that was the true foundation of the "American dream" [6]. Unemployment, inequality, widespread poverty, the pulverization of society brought the country to the brink of collapse and fratricidal wars such as those we are witnessing. The following graphs depict the end of the dream of equality and democracy that occurred in the same period as the end of the gold exchange standard (Figures $3 a$ and $3 b$ ).

Chinese manufacturing became the world's factory thanks to this 'creating shareholder value' mantra at the end of the 1980s when delocalisation became the shortest path to achieving maximum profit and the resulting liquidity. The path was opened to a metaphysical monetarism culture by depriving the country of manufacturing on which it had rebuilt its rebirth after the 1929 crisis [19-22]. But as always, history has its own tempo that we have unlearned to watch and link, and the fire prepared in the sixties exploded in 1968 and changed the destiny of the hopes of the young. At the end of those years, faced with a revolutionary thrust by individuals such as the Kennedys and Martin Luther King, society became afraid of change that was too close to a socialist model. Both King and Robert Kennedy were assassinated only a few months apart, the former in April and the latter in June. On 30 January 1968, [23-25] the violent Tet Offensive was launched that put an end to the illusory dreams of an easy war as it had been passed off, especially by General Westmoreland who had not understood or did not feel that he needed to understand who he was facing at the time, thereafter disqualified from command. The clash in Vietnam after Korea and the USA defeats represent the lack of historical culture in the country that entrusted everything to technical power, defeated on the social and political front. No one had seriously considered the story of General Nguyên Giáp who defeated the French at Dien Bien Phu in 1954, simulating the same strategy in the Tet Offense to mislead the USA command and the Japanese in 1945 in Hanoi [26-28]. The supposition, the lack of historical and political vision, the absence of true internal creative inspiration are critical elements of the USA, as the last 20 years of foreign policy demonstrate, linked only to the supposition of the technical domain that detaches man from his soul and renders sentiments sterile and aseptic. From there, in the face of student protests, libertarian movements, protests racism and war, the country turned the page, and those dreams of equal rights for all and equality for minorities, now majorities, swiftly turned towards the oligarchy and the dominion of the monetary and financial economy in social and political life. The concentration of wealth as an end and not the rebuilding of shared wellbeing destroys society because increasing social inequality explodes social ills with inequality, poverty, real and not manipulated unemployment, and finally with the 'homeless' to whom the Statue of Liberty had assured refuge (Figures 4a-4i) [29-31].

What degree of degradation must be reached before social weakness explodes in convulsive and aggressive reactions as we witness each day? The idea of omnipotence that devoured the US after the collapse of the Berlin Wall today clashes with the evidence of history that always proves that that societies cannot be more invulnerable than the extinct civilizations of the Aztecs and Incas, Sumerians, Hittites, Egyptians.

The painful nostalgia of those years reminds us of Robert Kennedy's famous speech on GDP where he demonstrated that a numeric indicator is fallacious in assessing the soul of a society and that its pursuit is a tragic step to arrive at considering economics/finance as an end and not a means. Man would then be definitively economized from the point of view of historical cycles as in 1968 that saw the definite transformation of a creative elite into a dominant elite whose purpose is to occupy the power to retain infinite dominance. In this way, the elite power lost contact with reality and above all its ability to respond creatively to the challenges posed by history, becoming ossified in the idea of endless omnipotence. The times of change are lengthy, but it is precisely in those years that a socialist and egalitarian America changed into an oligarchic and increasingly elite America that would end up forgetting its history blinded by the illusory dream of infinite power [32-35]. Today we see that the system is turning to this and the disaggregation between the dominant parties and against each other is the most obvious manifestation that we are facing a period of dangerous implosion. History defined its course, ending up in our day and certainly the fall of the Berlin Wall marked the end of the external 


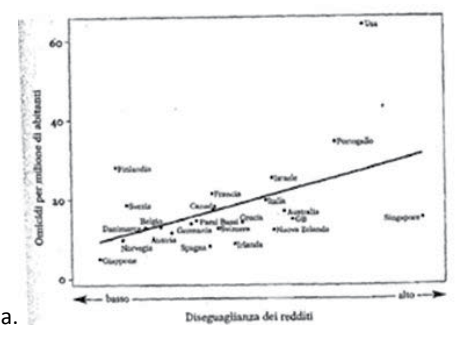

c.

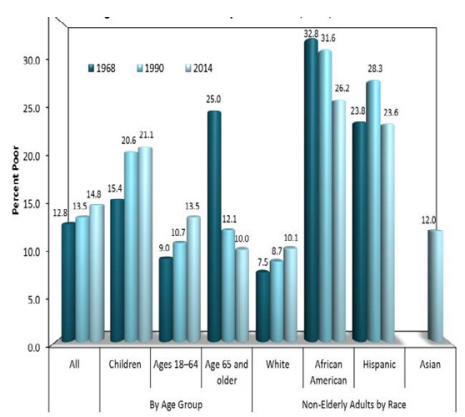

Number of Homeless People Each Nigh in the NYC Shelter System, 1983-2016

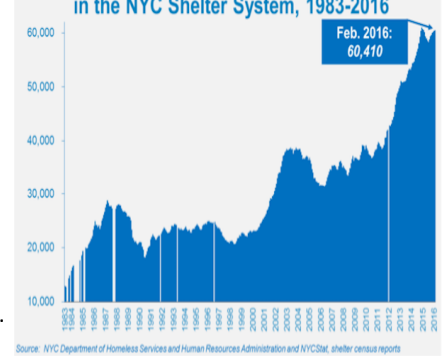

\section{Born Into Poverty (Whites)}

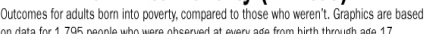

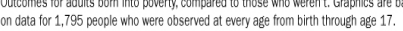

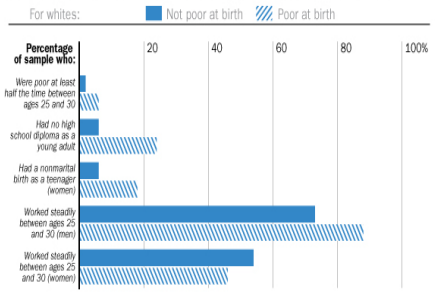

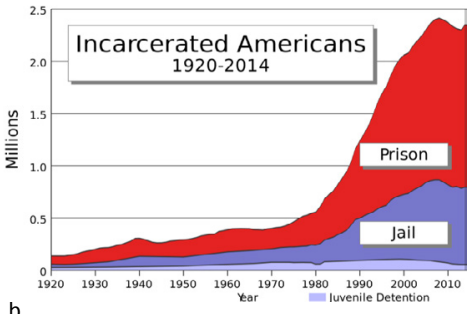

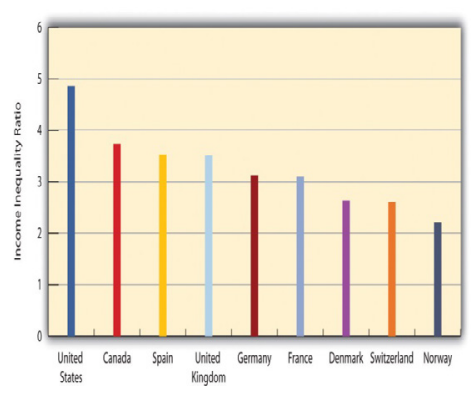

\section{U.S. Labor Force Trends: 2000 to 2016}
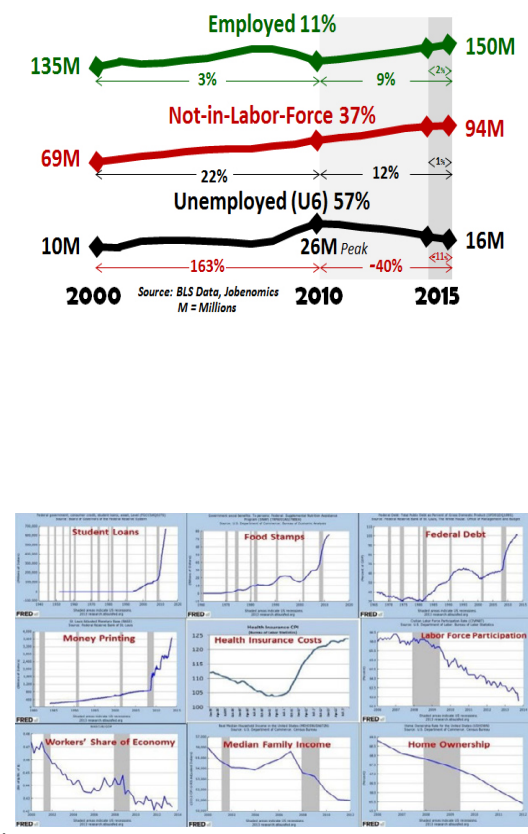

America will never be destroyed from the outside. If we falter and lose our freedoms, it will be because we destroyed ourselves.

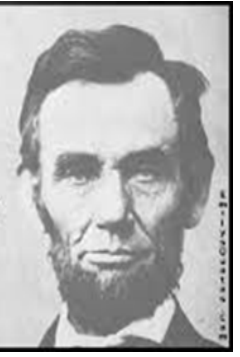

Figure 4a-4i: Statistics. 
opponent that tempered the dreams of domination and omnipotence $[7,9]$. Precisely the moment of breaking the Soviet empire could have been a turning point in history if the USA instead of pursuing the dominant culture of the elite in power had launched a sort of new Marshall plan with Europe to help Russia, then today we would have a different world more inclined to reflect on international cooperation to which a still-weak China could have adhered.

The 90s were the "red carpet" to sanctify finance with Nobel Prizes that were instrumental to the financial dominance of the elites at the expense of an ever-enhanced democracy, but more and more like a fantastic and non-existent dream. At the end of the century, Greenspan put the final seal on the moral devastation of finance and 2008 brought the first signal of the moral crisis of this finance, but once again the blame and the weight of wrong choices fell on the poor [36-39].

In this dramatic context, the US elections were held that allowed Trump to become president, elected by poor Americans with the same percentage of votes $61 \%$ as in Brexit and the Italian referendum. We are now in the reckoning and must start thinking about how good it is to separate the grain from the chaff and return to giving Caesar what is Caesar's and to God what is God's [40-42]. The USA is the only Western country not to have ever had a real social revolution, but its story seems to be a remake of the social clashes that characterized the infinite quest for a just and equitable society; it is always greed that destroys human societies in history. "In a society that discovered the 'know-how' of Amantea's cornucopia, the always ugly inequality in the distribution of this world's goods, in ceasing to be a practical necessity, has become a moral enormity" wrote Toynbee in 1948 in "Civilization on Trial" [43-45].

All societies have their intrinsic cycles- economic, political, and generational- characterized by excesses of optimism or pessimism, according to Toynbee who based his theory on the "balance of power" that becomes an unstable game in society in the search for dominance and the power of minorities, and the counter-revolutionary response of majorities in search of equality in a sort of Darwinian view of social evolution [46,47]. In this war, Toynbee separated the dominant minorities from the creators and this vision can be used to understand the historical cycle in which US society finds itself. When the dominant class loses its creativity, it tends to become obsessed and by the same token attracts ever-less professional and moral people who pursue elitist interests, and thus ends up stifling the relationship of interaction with most of the country, preventing the natural replacement of the ruling classes and the continuous exchange of ideas and ideals declared by the founding fathers. The dominant class pursues particularistic interests, loses connection with the real society that is abandoned by facilitating the disintegration that lead to the system's collapse. The social pathologies we have seen in the graphs show the degree of social deterioration and the distance between the elite and society. The process tends to degenerate to achieve a dream of omnipotence that becomes, as Keynes would say, the euthanasia of the rentier.

Euthanasia does not depend on an inhibition of the elite's mental faculties, but on its inability to maintain the moral legacy of those who have contributed with their creative impetus to the development of society or in a broader sense to a form of civilization. In this sense, the social drama of the USA also concerns Western civilization. Attention to particularistic interests nourishes the disintegration of the social web and the system of relationships that enable it to stand. As we can observe more fully in the US, but also in European countries, the dominant nucleus breaks into self-referential parts that ultimately determine the collapse of society that always has a spiritual and moral and not an economic and technical origin.

\section{Conclusion}

The decadence is not immediate and can take time, but in the present case, as we tried to point out, it began more clearly when in the late $60 \mathrm{~s}$ the fear perhaps of becoming too social a system - the word socialist was considered an intolerable condemnation- pushed elites into power to scale back a process that if unmanaged would be destabilizing. From that decade onwards, the system progressively pushed towards a materialistic model that found in financial liberalism its destructive weapon of domination, pushing for a progressive loss of temperance and undertaking adventurous actions, such as the wars at the beginning of the century, the mirage of infinite wealth of a financial illusion that represents the dream of omnipotence and an intoxication of a "victory" that as Toynbee claimed leads to defeat.

Trump's election, voted by the poorer classes in the same way as Brexit, is the first strong sign of the rejection of a cultural system and social model that has broken the country into a sort of internal war for domination. Only a creative response that can break through the sociocultural trends that have characterized society over the last 40 years can be the answer to a form of evolution towards a model that can rebuild the social capital on which human society has always been based. Once again and for the global good "God bless America".

\section{References}

1. Balthasar Von HU (2010) Homo Creatus Est.: Jaca Book, Milan, Italy.

2. Balzac-De H (1892) Illusions Perdues [Lost Illusions]. Calmann Lévy, Paris France.

3. Bauman Z (1998) Liquid Life. Laterza. Rome-Bari, Italy.

4. Bauman Z (2009) Parasitic Capitalism. Rome-Bari: Laterza, Italy.

5. Bloch E (1994) The Principle of hope, Garzanti, Milan, Italy.

6. Chomsky N (2006) Failed states: The abuse of power and the assault on democracy. II Saggiatore. Milan, Italy

7. Einstein A (1975) The world as i see it: Newton Compton Publisher, Rome, Italy.

8. Freud S (1971) The discomforts of civilization. Bollati Boringhieri Publisher, Turin, Italy.

9. Freud S (1971) The future of illusion. Bollati Boringhieri Publisher, Turin, Italy.

10. Freud S (1991) L'interpretazione dei Sogni [The Interpretation of Dreams] Bollati Boringhieri Publisher, Turin, Italy

11. Goethe JW (2005) Faust. Frankfurt: Deutscher Klassiker Verlag, Germany.

12. Guardini R (1954) The end of the modern world. Morcelliana Publishing, Brescia, Italy.

13. Kahneman D (2011) Thinking fast and slow. Mondadori Publishing, Milan, Italy

14. Kant I (2007) Perpetual peace. A philosophical sketch. Feltrinelli Publishing Milan, Italy.

15. Keynes JM (1991) Economic possibilities for our grandchildren. Bollati Boringhieri, Turin, Italy. pp. 321-332.

16. Keynes JM (1926) The end of laissez faire. London: MacMillan Publishers, UK.

17. Keynes JM (1933) Essays in Persuasion. London: MacMillan Publishers, UK.

18. Krugman $P$ (2012) End this depression now. NY Times.

19. Krugman $P$ (2009) How did economics get it so wrong? The NY magazine.

20. Kuhn TS (1969) The structure of scientific revolutions. Einaudi, Turin, Italy.

21. Milanovic B (2011) The haves and the have-nots. II Mulino, Bologna, Italy.

22. Pascal B (1994) Thoughts. Mondadori Publishing, Milan, Italy.

23. Pezzani F (2008) The Lucidity Pact. Egea, Milan, Italy.

24. Pezzani F (2011) Cooperative Competition. Egea-UBE, Milan, Italy.

25. Plato (1990) La Repubblica [The Republic]. Mondadori Publishing, Milan, Italy. 
26. Plato (2010) Phaedo. Rome-Bari: Laterza, Italy.

27. Plato (2012) Symposium. Feltrinelli, Milan, Italy.

28. Posner R (2010) The crisis of capitalist democracy. Egea-UBE, Milan, Italy.

29. Prigogine I (1996) La fin des certitudes. Temps chaos et les lois de la nature. Odile Jacob Publishing, Prais, France.

30. Putnam R (2004) Social capital and individualism. II Mulino, Bologna, Italy

31. Reich R (2008) Supercapitalism. Fazi Publisher, Rome, Italy.

32. Rousseau JJ (2009) Origin of inequality. Grafica Spiel, Milan, Italy.

33. Russell B (2009) The scientific outlook. Laterza, Rome, Italy.

34. Sen A (1999) Development as freedom. Oxford University Press, UK.

35. Sen A (2010) The Theory of Moral Sentiment. Penguin, UK

36. Severino E (2002) Techne. The Roots of Violence. Rizzoli, Milan, Italy.

37. Sorokin P (1975) Social and cultural dynamics. Utet Publisher, Turin, Italy.
38. Sorokin P (1941) The crisis of our age. Oxford: One World.

39. Stiglitz J (2012) The Price of inequality. How today's divided society endangers our future. New York: WW Norton \& Company, USA.

40. Toynbee AJ (1949) Civilization on Trial. Bompiani Publisher, Milan, Italy.

41. Toynbee AJ (1946) A study of history. Oxford University Press, UK

42. Toynbee AJ (1953) The world and the west Oxford University Press, UK.

43. Toynbee AJ (1977) Mankind and mother earth. Garzanti Publisher, Milan, Italy.

44. Toynbee AJ (1962) America and the world revolution Oxford University Press, UK.

45. Toynbee AJ (1966) Change and habit. The challenge of our time; Oxford University Press, UK.

46. Vico G (1722) La Scienza Nuova [The New Science]. Napoli, Italy.

47. Wilkinson R, Pickett K (2009) The spirit level. Feltrinelli Publishing, Milan, Italy. 